\title{
A double blind randomized clinical trial to investigate the effect of vitamin D supplementation on metabolic and hepato-renal markers in type 2 diabetes and obesity
}

\author{
Peivasteh Safarpour ${ }^{1}$, Mohammad Reza Vafa*1, Fatemehsadat Amiri ${ }^{1}$, Leila Janani ${ }^{2}$, Mitra Noorbakhsh ${ }^{3}$, \\ Ensieh Rajabpour Nikoo ${ }^{4}$, Homa Sadeghi ${ }^{5}$
}

Received: 23 Sep 2017

Published: 28 Apr 2018

\section{Abstract}

Background: According to the recent studies, vitamin D deficiency has been correlated with progress in type 2 Diabetes and Metabolic Syndrome. The aim of this study was to assess the effect of vitamin D supplementation on glucose and lipid profiles, blood pressure, and biomarkers of liver and kidney in type 2 diabetic patients.

Methods: In this Double blinded randomized clinical trial, 90 patients with type 2 diabetes and serum 25-Hydroxy vitamin D levels of less than $30 \mathrm{ng} / \mathrm{ml}$ recruited from "Besat Diabetes Clinic" in Rasht, North of Iran. The subjects took 50000 IU vitamin D supplements or placebo for 8 weeks. We assessed the levels of serum $25(\mathrm{OH})$ vitamin D, glucose and lipid profiles, oxidative and inflammatory indices, liver and kidney biomarkers, blood pressure, and sun exposure time, physical activity before and after intervention, and compared them between cases and controls.

Results: Vitamin D supplementation significantly increased serum vitamin D level, Superoxide Dismutase (SOD) activity, and significantly decreased serum HbA1C (Glycosylated Hemoglobin) level $(\mathrm{p}<0.001)$. High Density Lipoprotein (HDL) Cholesterol increased significantly $(\mathrm{p}=0.016)$, and Erythrocyte Sedimentation Rate (ESR) significantly decreased $(\mathrm{p}=0.039)$ after the intervention.

Conclusion: Our results represented that weekly supplementation with $50000 \mathrm{IU}$ vitamin D for 8 weeks may be effective by improving $\mathrm{HbA1C}$ and lipid profile in type 2 diabetes mellitus.

Keywords: Vitamin D, Glucose, Diabetes, Lipid, Diet, Nutrition, Liver, Kidney, Type 2 diabetes, Inflammation

Copyright $\odot$ Iran University of Medical Sciences

Cite this article as: Safarpour P, Vafa MR, Amiri F, Janani L, Noorbakhsh M, Rajabpour Nikoo E, Sadeghi H. A double blind randomized clinical trial to investigate the effect of vitamin D supplementation on metabolic and hepato-renal markers in type 2 diabetes and obesity. Med $J$ Islam Repub Iran. 2018(28 Apr);32:34. https://doi.org/10.14196/mjiri.32.34

\section{Introduction}

Diabetes is defined as a metabolic disease related to insulin secretion, sensitivity, dysfunction and resistance, leading to increased serum glucose (1). Type 2 Diabetes Mellitus (T2DM) may have been the result of several pathogenic mechanisms such as pancreatic Beta cell dysfunction, increased serum insulin level, and insulin resistance (2). One of the major risk factors of T2DM is obesity which leads to cellular oxidative stress, insulin resistance, and Beta cellular dysfunction (3). Furthermore, chronic increase in serum glucose due to T2DM is closely related to disrupting the normal function of organs such as

Corresponding author: Dr Mohammad Reza Vafa, rezavafa@yahoo.com

1. Department of Nutrition, School of Public Health, Iran University of Medical Sciences, Tehran, Iran.

2. Department of Biostatistics, School of Public Health, Preventive Medicine and Public Health Research Center, Iran University of Medical Sciences, Tehran, Iran.

3. Department of Biochemistry, School of Medicine, Iran University of Medical Sciences, Tehran, Iran.

4. Department of Medicine, School of Medicine, Guilan University of Medical Sciences, Guilan, Iran.

5. Department of Epidemiology, School of Massachusetts Lowell, Massachusetts, USA. kidney, heart, liver, central and peripheral nervous system, and cornea during long time (4).

Cardiovascular disease (CVD) is the main cause of mortality among people with T2DM reportedly 2-4 times more prone to CVD risk comparing those without T2DM. Furthermore, high serum lipid profiles is the main risk factor for CVDs among T2DM cases $(5,6)$. On the other side, vitamin D deficiency has been considerably increased among all age groups, and it has been reported that several cities in Iran vitamin D deficiency is highly prevalent. Besides Iran, Pakistan has reported 90\% overall

$\uparrow$ What is "already known” in this topic:

While observational studies suggest that there is an inverse relationship between vitamin D levels in T2DM, but its relationship with insulin resistance is still unclear, and the results of interventional studies are generally contradictory.

\section{$\rightarrow$ What this article adds:}

Weekly supplementation with 50000 IU vitamin D for 8 weeks may be effective by improving $\mathrm{HbA} 1 \mathrm{C}$, lipid profile and inflammatory factor of ESR in type 2 diabetes mellitus. 
prevalence of vitamin D deficiency, 48-60\% and 40-70\% among Chilean and Brazilian healthy postmenopausal women respectively. Less than $50 \%$ of world's population have been reported with sufficient serum vitamin D (710) .According to a meta-analysis by Akbari and coworkers, vitamin D supplementation may significantly decrease Insulin resistance markers (HOMA-IR and HOMA B), and LDL cholesterol levels. However, they did not observed significant increase in fasting glucose and HDL serum levels (11)

Insulin resistance is one of the main causes of T2DM, and according to recent studies, vitamin D has had inverse association with insulin resistance which may include vitamin D deficiency as a risk factor for incident T2DM (10-13). Moreover, vitamin D deficiency and T2DM have common risk factors such as obesity, age, and sedentary life style, and serum level of $25(\mathrm{OH})$ vitamin $\mathrm{D}$ has been reported significantly low comparing those without T2DM $(14,15)$. Some studies have found direct relationship between $25(\mathrm{OH})$ vitmin D levels and Insulin secretion in Pancreatic Beta cells, and some studies have demonstrated that vitamin D has anti-inflammatory effects (16).

In some degenerative diseases such as Insulin Dependent Diabetes Mellitus (IDDM), active oxygen metabolites can deteriorate the disease by increasing oxidative stress if they are not scavenged by body's antioxidant defense system (17). Besides, hyperglycemia, hyperlipidemia, and increased inflammatory cytokines strengthen the risk of inflammation and metabolic risk (18).

Since recent studies are controversial about the effect of vitamin D on glycemic control, we aim to find the effect of vitamin D on lipid and glycemic profile, antioxidant factors, liver and kidney biomarkers in T2DM cases. In our double blinded randomized Clinical Trial, we give vitamin D supplements to the intervention group to find out if vitamin D improves insulin resistance, and glycemic index in T2DM.

\section{Methods}

Current study is a double blinded randomized Clinical Trial, of the random assignment type, on 90 subjects with T2DM who visit "Besat" Specialist Clinic in Rasht; Gilan province, North of Iran, from the beginning until the end of autumn in 2016 .

As it is shown in Diagram 1, after admitting the patients to the clinic, they were asked to participate in the project if they were interested. After signing the "written informed" consent, we randomly divided them into 2 groups of intervention and control. Intervention was implied by eight 50000 IU vitamin D pearls, and the placebo included oral paraffin manufactured by Zahravi PharmaceuticalsIran. We asked the subjects to take one tablet per week for 8 weeks. During the intervention period, we had a weekly phone call follow-up with each subject and asked them if they took their supplement, and also about the probable side effects and complications of using supplements. We recorded the number of used pearls as well as returned blisters and packs.

The inclusion criteria were Diagnosed T2DM in both males and females, 25-65 year old, Serum $25(\mathrm{OH})$ vita-

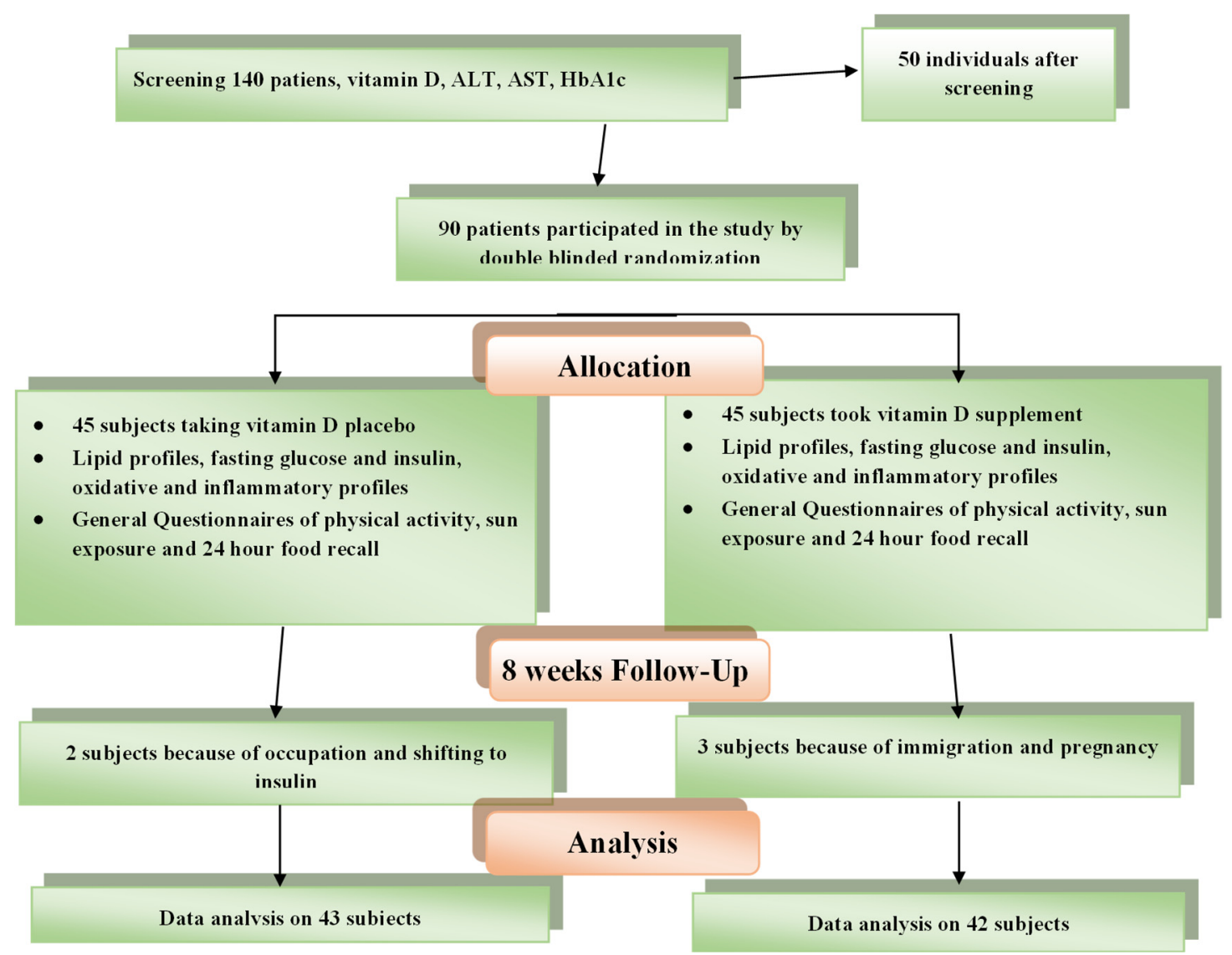

Diagram 1. According to flow diagram of participants, 3 patients in the intervention group and 2 patients in the placebo group were excluded 
$\min \mathrm{D}<30 \mathrm{ng} / \mathrm{ml}$, Body Mass Index (BMI) between 25 to $35 \mathrm{~kg} / \mathrm{m}^{2}, \mathrm{HbA} 1 \mathrm{c}<8.5 \%$. Exclusion Criteria were frequent consumption of supplements, any acute disease, modification in type or dose of hyperglycemia medication, and decision to discontinue compliance.

We measured anthropometric characteristics, systolic and diastolic blood pressure, in the beginning and at the end of study. Subjects were weighted for being fasted, and notbeing in first 5 days of menstrual cycle to eliminate possible weight changing factors. Subjects were standing without shoes, and minimal cloths, on Seca scales with $100 \mathrm{~g}$ accuracy. Height measurement was done in standing position without shoes, straight head, flat feet against wall, arms at sides, looking straight by Seca eca Height easure $(0.5 \mathrm{~cm}$ accuracy). Body Mass Index (BMI) was calculated by deviding weight to square height $\left(\mathrm{kg} / \mathrm{m}^{2}\right)$.

Furthermore, we collected 24 hour food recalls from each subject in 2 non-consecutive days (one week day and one weekend day). We assessed their physical activity via short International Physical Activity Questionnaire (IPAQ) (19), and sun exposure by "sun exposure questionnaire" (20).

We collected $10 \mathrm{ml}$ blood from Brachial vain for measuring serum vitamin D, Glucose, fasting insulin, Glycosylated Hemoglobin, total cholesterol, HDL cholesterol, HDL cholesterol, Triglyceride, SOD and Glutathione Peroxidase as the antioxidant enzymes activity, inflammatory markers including hsCRP and ESR, hepatic enzymes including ALT and AST, and renal biomarkers including Blood Urea Nitrogen (BUN) and Serum Creatinine.

All biochemical tests were conducted by Olympus analyzer and Delta kits. We used Alpha Classic analyzer for rechecking samples with ESR higher than 30. We used serum for all samples except HbAlc and ESR. We used Fiedewald formula for LDL cholesterol measurement. Measuring Glycosilated hemoglobins, we used Nycocard kit in Nyco Card Reader (Made in Norway). Insulin was measured by Cobas e 411, with normal range of 2.6-24.9 $\mathrm{U} \mu / \mathrm{ml}$ and Roche Kit.

SOD was measured by "Zellbio GmbH (Germany), and normal range of SOD activity between U/ml100-5, and also Gluthathione Peroxidaze by "Zellbio GmbH (Germany) and activity range of 20-500 U/ml, Elisa method and Elisa Reader model "Tecan A-5082" (Austria). We measured $25(\mathrm{OH})$ vit D by quantitative diagnosis $25(\mathrm{OH}) \mathrm{D}_{3}$ kit from ImmunoDiagnostic Systems (IDS), UK which is an Enzyme Immunoassay kit with sensitivity of $5 \mathrm{mmol} / \mathrm{l}$ by ELISA method and Elisa Reader, Enzyme Immunoassay model ( Austria). Insulin resistance was assessed by HOMA-IR index and insulin sensitivity was evaluated by QUICKI $(21,22)$.

Insulin resistance $=$ [fasting serum glucose $(\mathrm{mmol} / \mathrm{l}) *$ fasting insulin $(\mu \mathrm{IU} / \mathrm{ml})] / 22.5$

Insulin sensitivity $=1 /$ Fasting insulin concentration $(\mu \mathrm{IU} / \mathrm{ml})+$ fasting glucose concentration $(\mathrm{mmol} / \mathrm{l})]$

\section{Sampling}

Since the primary outcomes of this study were serum level of 25-hydroxy vitamin D, Glycosylated hemoglobin (HbA1c), Insulin Resistance (HOMA-IR), and insulin sensitivity (QUICKI) we calculated the sample size using insulin resistance index based on Baziar and coworkers' study (23). Based on 1.33 unit difference of mean insulin resistance between two study groups after intervention, 1.18 standard deviation for vitamin D group and 2.84 Standard Deviation for placebo group, and 5\% probability of type- 2 error, and $80 \%$ power, we calculated our sample size by G-Power software and sample size calculation formula for comparison of two independent groups. Our sample size was 40 accordingly, and we recruited 45 subjects considering probable withdrawal.

Randomization was implied by 23 quadratic blocks via (www.sealedenvelope.com) website. For blinding, we used unique codes for each subject produced by software, and subjects were not aware to be either in intervention or placebo group.

\section{Analysis}

We analyzed the data using SPSS24. We described quantitative variables by mean and standard deviation and to describe the qualitative variables, a frequency report (percent) was used.

To compare the mean of quantitative outcomes between the two groups, independent t-test or its non-parametric equivalence, i.e., Mann-Whitney test were used and Chisquare test was used to compare qualitative variables between the two groups.

Also compared the results before and after intervention within each group by Paired t-test. We adjusted baseline characteristics for confounders, and ran ANCOVA models, and considered P-value $<0.05$ as the statisticalsignificant value. Nutritional status and nutrients intake was analyzed by Nutritionist software (version 4).

\section{Ethics}

Iran University of Medical Sciences Ethics Committee approved this clinical trial with Ethics Number of IR.IUMS.REC.1395.9223475201 in 05/09/2016 and record number of IRCT201604202365N11, and the participants signed the consent and participated in the project as volunteers.

Vitamin D intervention dose was equal to the National Institute of Health recommendations for treatment of vitamin D insufficiency and deficiency (50000 IU weekly for 8 weeks). Thus, lowest side effects had been expected after supplement intake (24). They could leave the project whenever they were not interested to continue. Furthermore, all of the ethical obligations were followed according to Helsinki ethical principles during blood sampling, and anthropometric measurements as well as confidentiality of subjects' information (25) also, after termination of intervention we gave vitamin D supplements to placebo group according to the Protocol.

\section{Results}

The mean and standard deviation of BMI in the vitamin $\mathrm{D}$ and placebo group were 30.43 (3.2) and 31.37 (3.4), respectively (weight range of $59-115 \mathrm{~kg}$, and height $=163.5-184 \mathrm{~cm}$ ), and mean age of 50 years (age 


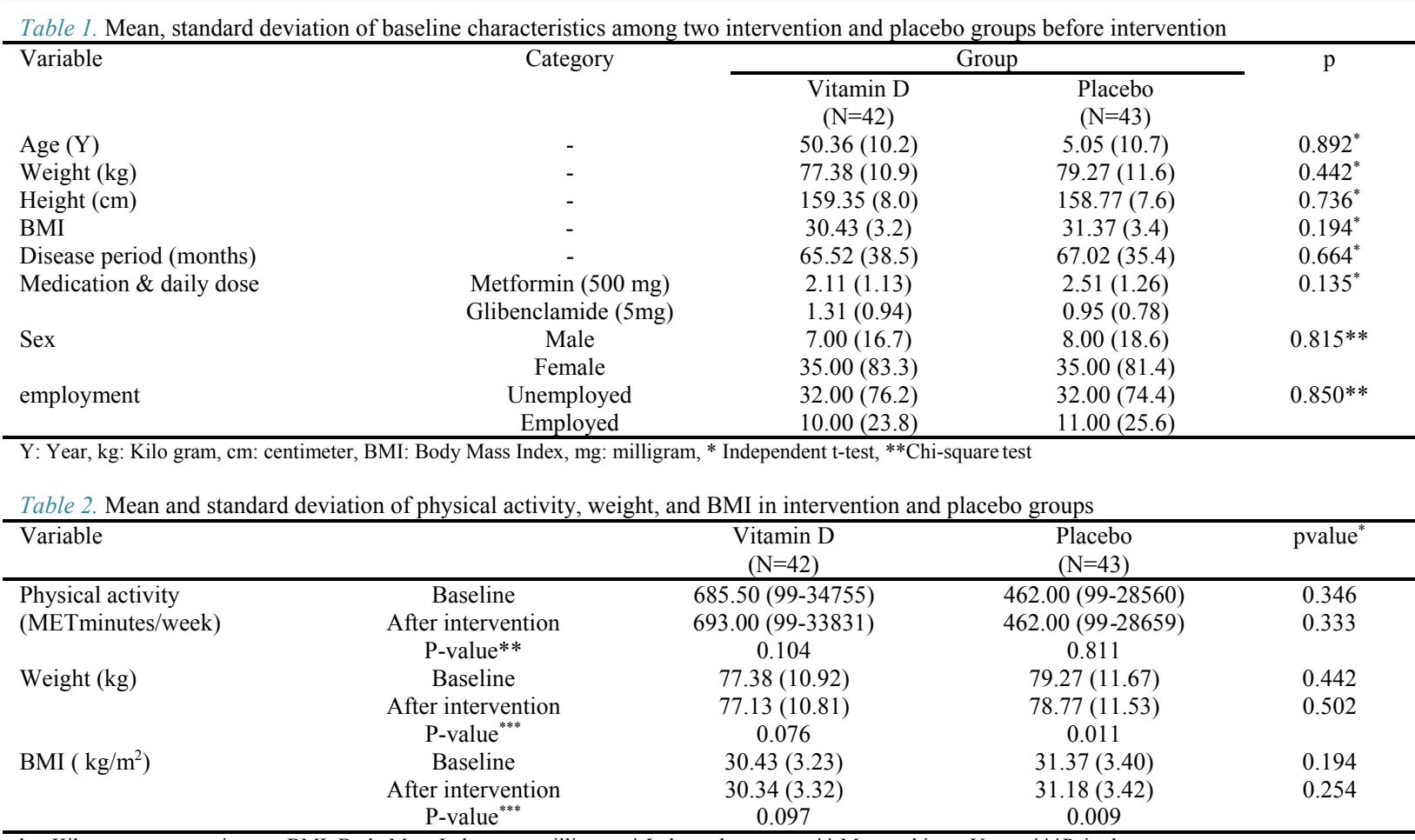

kg: Kilo gram; cm: centimeter; BMI: Body Mass Index; mg: milligram, ${ }^{*}$ Independent t-test , ${ }^{* *}$.Mann-whitney U test, ${ }^{* * *}$ Paired t-test

range of 25-65 years), diagnosed with T2DM since 6 years ago, and used at least two types of hyperglycemia treatment medicines. According to the results of Table 1 there was not a significant difference between intervention and placebo group in terms of baseline characteristics including age, sex, weight, height, BMI, Disease period, type and dose of medications ( between group P-value).

There was not a significant difference in weight, BMI, and physical activity between intervention and placebo group before and after intervention (Between groups Pvalue). Furthermore, there was no significant difference in each of placebo and intervention group before and after intervention (within group P-value) (Table 2).
Mean and standard deviation of energy intake, macronutrients, and micronutrients from diet was not significantly different between placebo and vitamin D groups before and after intervention, and also between each of placebo and vitamin D before and after intervention. We asked the participants not to change their ordinary diet during 8 weeks of intervention. Since current study was conducted from early fall season until the end of fall, sun exposure did not changed during the study period (Table 3 ).

According to the findings of Tables 1,2, and 3, we did not find significant difference before and after intervention, in the probable confounding variables comprising age, weight, sex, height, BMI, marital status, education

Table 3. Mean and standard deviation of energy intake, macronutrients, and micronutrients before and after intervention among vitamin D and placebo groups

\begin{tabular}{|c|c|c|c|c|}
\hline & & $\begin{array}{l}\text { Vitamin D } \\
(\mathrm{N}=42)\end{array}$ & $\begin{array}{l}\text { Placebo } \\
(\mathrm{N}=43)\end{array}$ & pvalue \\
\hline Energy & Baseline & $1638.59(377.82)$ & $1578.38(399.64)$ & 0.478 \\
\hline (kcal/day) & $\begin{array}{l}\text { After intervention } \\
\text { P-Value }\end{array}$ & $\begin{array}{c}1701.36(485.61) \\
0.381\end{array}$ & $\begin{array}{c}1564.68(392.75) \\
0.871\end{array}$ & 0.157 \\
\hline Protein & Baseline & $82.27(23.34)$ & $78.79(31.82)$ & 0.568 \\
\hline (g/day) & $\begin{array}{l}\text { After intervention } \\
\qquad \text { P-Value }\end{array}$ & $\begin{array}{c}89.31(35.83) \\
0.190\end{array}$ & $\begin{array}{c}80.31(32.16) \\
0.823\end{array}$ & 0.226 \\
\hline $\begin{array}{l}\text { Carbohydrate } \\
\text { (g/day) }\end{array}$ & $\begin{array}{c}\text { Baseline } \\
\text { After intervention } \\
\text { P-Value }\end{array}$ & $\begin{array}{c}232.69(67.62) \\
231.41(62.34) \\
0.891\end{array}$ & $\begin{array}{c}220.85(54.71) \\
214.21(51.19) \\
0.522\end{array}$ & $\begin{array}{l}0.377 \\
0.168\end{array}$ \\
\hline $\begin{array}{l}\text { Total fat } \\
\text { (g/day) }\end{array}$ & $\begin{array}{c}\text { Baseline } \\
\text { After intervention } \\
\text { P-Value }\end{array}$ & $\begin{array}{c}47.61(11.25) \\
51.31(17.33) \\
0.199\end{array}$ & $\begin{array}{c}46.83(12.22) \\
47.41(14.13) \\
0.830\end{array}$ & $\begin{array}{l}0.760 \\
0.258\end{array}$ \\
\hline $\begin{array}{l}\text { SFA } \\
\text { (g/day) }\end{array}$ & $\begin{array}{c}\text { Baseline } \\
\text { After intervention } \\
\text { P-Value }\end{array}$ & $\begin{array}{c}16.10(4.58) \\
16.01(6.10) \\
0.913\end{array}$ & $\begin{array}{c}15.35(3.75) \\
15.74(4.54) \\
0.639\end{array}$ & $\begin{array}{l}0.413 \\
0.819\end{array}$ \\
\hline $\begin{array}{l}\text { MUFA } \\
\text { (g/day) }\end{array}$ & $\begin{array}{c}\text { Baseline } \\
\text { After intervention } \\
\text { P-Value }\end{array}$ & $\begin{array}{c}16.06(3.85) \\
17.13(5.85) \\
0.265\end{array}$ & $\begin{array}{c}15.59(5.07) \\
15.56(4.86) \\
0.976\end{array}$ & $\begin{array}{l}0.636 \\
0.182\end{array}$ \\
\hline $\begin{array}{l}\text { PUFA } \\
\text { (g/day) }\end{array}$ & $\begin{array}{c}\text { Baseline } \\
\text { After intervention } \\
\text { P-Value }^{2}\end{array}$ & $\begin{array}{c}9.98(3.04) \\
10.49(2.47) \\
0.365 \\
\end{array}$ & $\begin{array}{c}10.04(3.45) \\
9.97(3.86) \\
0.919\end{array}$ & $\begin{array}{l}0.836 \\
0.480\end{array}$ \\
\hline
\end{tabular}

1. Independent t-test, 2. Paired t-test, SFA: saturated fatty acid, MUFA: Mono Unsaturated Fatty Acid, PUFA: Poly Unsaturated Fatty Acid. 


\begin{tabular}{|c|c|c|c|c|c|}
\hline Calcium & Baseline & \multicolumn{2}{|c|}{$835.33(279.75)$} & $838.41(301.51)$ & 0.961 \\
\hline (mg/day) & $\begin{array}{l}\text { After intervention } \\
\text { P-Value }\end{array}$ & \multicolumn{2}{|c|}{$\begin{array}{c}804.44(324.89) \\
0.487\end{array}$} & $\begin{array}{c}833.63(292.95) \\
0.929\end{array}$ & 0.665 \\
\hline Phosphorus & Baseline & \multicolumn{2}{|c|}{$1444.29(402.18)$} & $1364.80(372.84)$ & 0.347 \\
\hline (mg/day) & $\begin{array}{l}\text { After intervention } \\
\text { P-Value }\end{array}$ & \multicolumn{2}{|c|}{$\begin{array}{c}1459.15(467.88) \\
0.814\end{array}$} & $\begin{array}{c}1355.23(388.99) \\
0.897\end{array}$ & 0.268 \\
\hline Vitamin D & Baseline & \multicolumn{2}{|c|}{$1.73(1.28)$} & $1.84(1.41)$ & 0.710 \\
\hline$(\mathrm{ng} / \mathrm{ml})$ & $\begin{array}{l}\text { After intervention } \\
\text { P-Value }\end{array}$ & \multicolumn{2}{|c|}{$\begin{array}{c}1.58(1.18) \\
0.386\end{array}$} & $\begin{array}{c}1.64(1.22) \\
0.334\end{array}$ & 0.835 \\
\hline $\begin{array}{l}\text { Total fiber } \\
\text { (g/day) }\end{array}$ & $\begin{array}{c}\text { Baseline } \\
\text { After intervention } \\
\mathrm{p}^{2}\end{array}$ & $\begin{array}{r}29 . \\
29\end{array}$ & & $\begin{array}{c}26.58(7.56) \\
25.91(9.05) \\
0.603 \\
\end{array}$ & $\begin{array}{l}0.192 \\
0.578\end{array}$ \\
\hline & & $\begin{array}{c}\text { Vitamin D } \\
(\mathrm{N}=42) \\
\end{array}$ & $\begin{array}{l}\text { Placebo } \\
(\mathrm{N}=43)\end{array}$ & Crude pvalue $^{2}$ & $\begin{array}{c}\text { Adjusted } \\
\text { pvalue }^{3}\end{array}$ \\
\hline $\begin{array}{l}\text { VitaminD } \\
(\mathrm{ng} / \mathrm{ml})\end{array}$ & $\begin{array}{c}\text { Baseline } \\
\text { After intervention } \\
\text { P-value }\end{array}$ & $\begin{array}{c}17.24(7.83) \\
38.86(10.76) \\
<0.001\end{array}$ & $\begin{array}{c}17.56(7.82) \\
14.79(7.08) \\
<0.001\end{array}$ & $\begin{array}{c}0.853 \\
<0.001\end{array}$ & $<0.001$ \\
\hline $\begin{array}{l}\mathrm{HbA} 1 \mathrm{c} \\
(\%)\end{array}$ & $\begin{array}{c}\text { Baseline } \\
\text { After intervention } \\
\text { P-value }{ }^{2}\end{array}$ & $\begin{array}{c}7.51(0.87) \\
6.76(0.98) \\
<0.001\end{array}$ & $\begin{array}{c}7.15(1.12) \\
7.21(1.11) \\
0.657\end{array}$ & $\begin{array}{l}0.103 \\
0.051\end{array}$ & $<0.001$ \\
\hline $\begin{array}{l}\text { HOMA-IR } \\
(\mathrm{N})\end{array}$ & $\begin{array}{c}\text { Baseline } \\
\text { After intervention } \\
\text { P-value }\end{array}$ & $\begin{array}{c}5.36(3.23) \\
6.44(3.73) \\
0.006\end{array}$ & $\begin{array}{c}5.83(3.09) \\
7.39(4.58) \\
0.003\end{array}$ & $\begin{array}{l}0.499 \\
0.295\end{array}$ & 0.421 \\
\hline $\begin{array}{l}\text { Quicki } \\
\text { (N) }\end{array}$ & $\begin{array}{c}\text { Baseline } \\
\text { After intervention } \\
\text { P-value }\end{array}$ & $\begin{array}{c}0.76(0.08) \\
0.73(0.07) \\
0.005\end{array}$ & $\begin{array}{c}0.73(0.06) \\
0.71(0.07) \\
0.003\end{array}$ & $\begin{array}{l}0.149 \\
0.217\end{array}$ & 0.645 \\
\hline
\end{tabular}

1. Independent t-test, 2. Paired t-test, 3. ANCOVA

level, duration of diabetes, and nutritional factors (dietary Vitamin D), energy, calcium, phosphorus, Poly Unsaturated Fatty Acid (PUFA), Unsaturated Fatty Acid (SFA), Unsaturated Fatty Acid (MUFA), fiber, carbohydrate, and protein), physical activity, and sun exposure. Therefore, we considered mentioned factors as controlled variables and for both primary and secondary outcomes, we conducted ANCOVA analysis only adjusting the baseline values.

Among all of the primary outcomes, vitamin D and
Glycosilated hemoglobin represented significant difference after intervention comparing baseline (Post intervention between group p-value $<0.001)$. Serum vitamin D level was doubled after intervention, and glycosylated hemoglobin decreased 1\% in intervention group (Table 4).

According to the results of Table 5, among all of the secondary outcomes, HDL cholesterol, SOD, and ESR represented significant difference $(\mathrm{P}<0.05)$ between vitamin $\mathrm{D}$ and placebo group after intervention (Table 5).

Table 5. Mean and Standard Deviation of secondary variable before and after intervention among 2 groups of intervention and placebo

\begin{tabular}{|c|c|c|c|c|c|}
\hline & & $\begin{array}{l}\text { Vitamin D } \\
(\mathrm{N}=42)\end{array}$ & $\begin{array}{l}\text { Placebo } \\
(\mathrm{N}=43)\end{array}$ & pvalue $^{1}$ & $\begin{array}{c}\text { Adjusted } \\
\text { pvalue }^{3}\end{array}$ \\
\hline FBS & Baseline & $172.48(62.16)$ & $178.28(71.74)$ & 0.629 & 0.130 \\
\hline$(\mathrm{mg} / \mathrm{dl})$ & $\begin{array}{l}\text { After intervention } \\
\text { P-value }\end{array}$ & $\begin{array}{c}175.52(65.44) \\
0.742\end{array}$ & $\begin{array}{c}162.72(61.36) \\
0.053\end{array}$ & 0.355 & \\
\hline Insulin & Baseline & $12.64(5.94)$ & $14.09(6.43)$ & 0.284 & 0.101 \\
\hline$(\mathrm{mic} I \mathrm{U} / \mathrm{ml})$ & $\begin{array}{l}\text { After intervention } \\
\quad \text { P-value }\end{array}$ & $\begin{array}{c}15.31(7.24) \\
0.002\end{array}$ & $\begin{array}{c}18.77(9.02) \\
<0 / 001\end{array}$ & 0.055 & \\
\hline LDL cholesterol (mg/dl) & $\begin{array}{c}\text { Baseline } \\
\text { After intervention } \\
\text { P-value }\end{array}$ & $\begin{array}{c}104.60(42.74) \\
104.71(27.94) \\
0.985\end{array}$ & $\begin{array}{c}105.98(33.43) \\
95.60(30.26) \\
0.017\end{array}$ & $\begin{array}{l}0.868 \\
0.153\end{array}$ & 0.086 \\
\hline $\begin{array}{l}\text { HDL cholesterol } \\
(\mathrm{mg} / \mathrm{dl})\end{array}$ & $\begin{array}{c}\text { Baseline } \\
\text { After intervention } \\
\text { P-value }\end{array}$ & $\begin{array}{c}49.10(11.31) \\
51.64(8.48) \\
0.091\end{array}$ & $\begin{array}{c}46.42(8.02) \\
46.28(9.38) \\
0.905\end{array}$ & $\begin{array}{l}0.211 \\
0.007\end{array}$ & 0.016 \\
\hline $\begin{array}{l}\text { TG } \\
(\mathrm{mg} / \mathrm{dl})\end{array}$ & $\begin{array}{c}\text { Baseline } \\
\text { After intervention } \\
\text { P-value }\end{array}$ & $\begin{array}{c}180.69(74.47) \\
187.14(85.47) \\
0.574\end{array}$ & $\begin{array}{c}201.72(125.41) \\
218.16(187.68) \\
0.354\end{array}$ & $\begin{array}{l}0.349 \\
0.332\end{array}$ & 0.684 \\
\hline $\begin{array}{l}\text { Total cholesterol } \\
(\mathrm{mg} / \mathrm{dl})\end{array}$ & $\begin{array}{c}\text { Baseline } \\
\text { After intervention } \\
\text { P-value }\end{array}$ & $\begin{array}{c}190.21(55.46) \\
192.10(35.35) \\
0.809\end{array}$ & $\begin{array}{c}192.63(46.10) \\
183.70(42.93) \\
0.094\end{array}$ & $\begin{array}{l}0.828 \\
0.328\end{array}$ & 0.181 \\
\hline $\begin{array}{l}\text { AST } \\
(\mathrm{U} / \mathrm{L})\end{array}$ & $\begin{array}{c}\text { Baseline } \\
\text { After intervention } \\
\text { P-value }\end{array}$ & $\begin{array}{c}20.52(5.73) \\
19.93(5.09) \\
0.544\end{array}$ & $\begin{array}{c}21.37(6.10) \\
22.09(7.72) \\
0.451\end{array}$ & $\begin{array}{l}0.511 \\
0.131\end{array}$ & 0.177 \\
\hline $\begin{array}{l}\text { ALT } \\
(\mathrm{U} / \mathrm{L})\end{array}$ & $\begin{array}{c}\text { Baseline } \\
\text { After intervention } \\
\text { P-value }\end{array}$ & $\begin{array}{c}22.74(8 / 93) \\
22.67(8 / 21) \\
0.949\end{array}$ & $\begin{array}{c}23.98(9 / 04) \\
26.02(11 / 27) \\
0.118\end{array}$ & $\begin{array}{l}0.527 \\
0.127\end{array}$ & 0.134 \\
\hline
\end{tabular}

1.2Independent t-test, 2. Paired t-test, 3. ANCOVA 


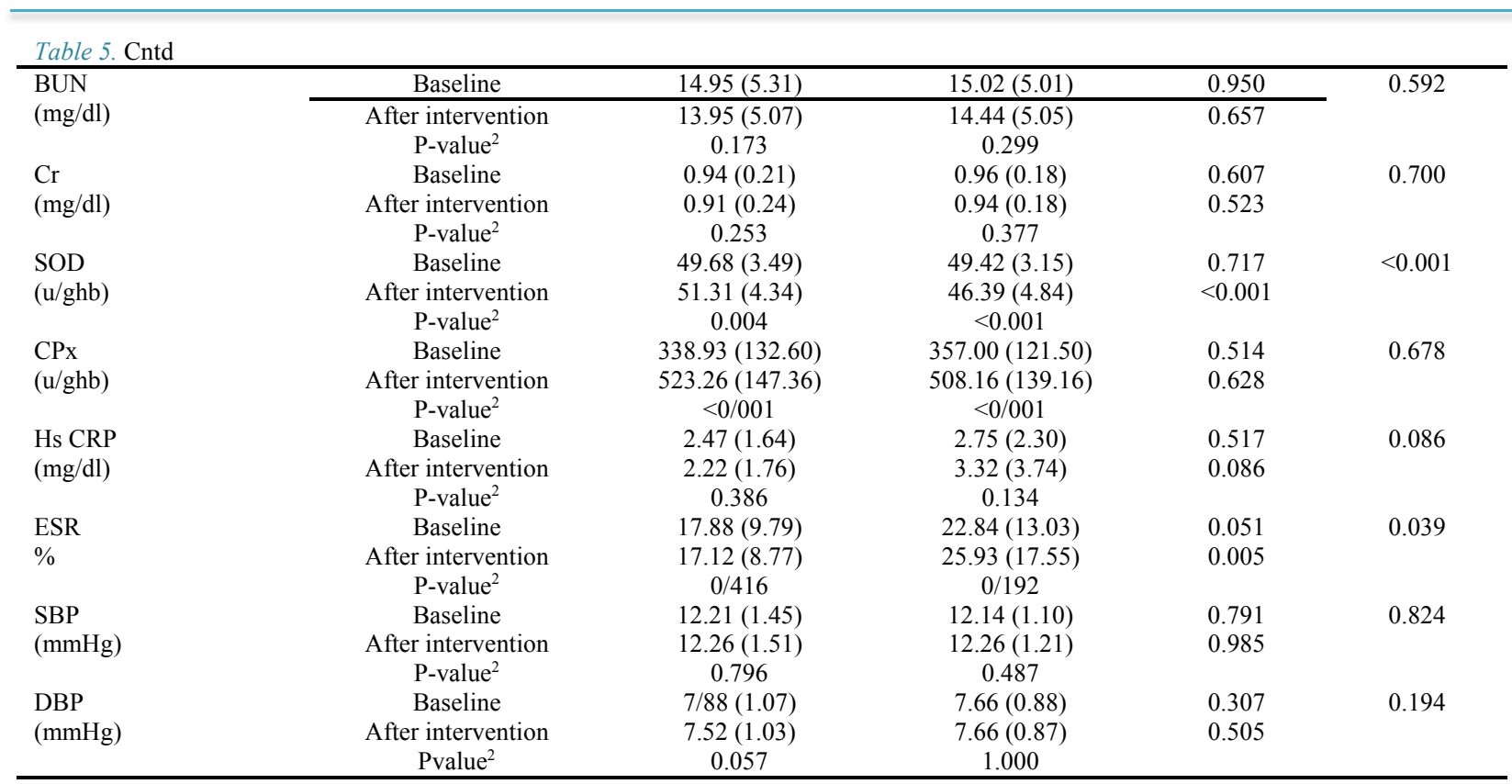

\section{Discussion}

The aim of this study was to assess the effect of vitamin D supplementation on glucose and lipid profiles, blood pressure, and biomarkers of liver and kidney in type 2 diabetic patients.

Weekly intake of 50,000 IU Vitamin D supplement for 8 weeks resulted in descending HBA1c, and ESR, and elevation of HDL cholesterol, and SOD levels.

According to the outcomes of this study, mean serum $(\mathrm{OH})$ vitmin D3 level increased by two times at the baseline after 8 weeks intervention. Whereas, the placebo group represented lower serum vitamin $\mathrm{D}$ at the end of the study.

The results of this study is along with some similar studies such as Borissova and coworkers' study in 2003 according which daily intake of 1322 IU Calcitriol supplement for one month, increased insulin secretion and decreased insulin resistance (26). Heshmat and colleagues found that intramuscular injection of 300,000 IU vitamin $\mathrm{D}$ did not change anthropometric, HbA1c, and HOMA index (27). In a study by Nasri and coworkers in 2014, dose of vitamin D was similar to our study (weekly 50,000 IU), and they found that vitamin D group had lower HbA1c after intervention (28). SUNNY trial in 2015 represented no significant modification in $\mathrm{HbAlc}$ and other glycemic indicators after 6 months of 50000 IU vitamin D supplementation among 275 subjects (29). Al-Daghri and coworkers in 2011 demonstrated that $25(\mathrm{OH})$ vitmin $\mathrm{D}$ is inversely associated with obesity, insulin resistance and LDL levels among Soudi subjects with T2DM (30). In a cross-sectional study by Nielsen and coworkers in 2016, not only there was no support on the hypothesized positive effect of vitamin D on risk of T2DM, but they also found that higher vitamin D levels were in a weak positive association with fasting serum glucose level (31).

The mentioned controversy among recent studies may have been due to variety of dietary patterns, timing and type of hyperglycemia medications, and the effect of genetic factors among different study populations.
The effect of Vitamin D supplementation on increased fasting serum insulin level was not significant $(p=0.10)$ after adjusting the analysis for baseline measurements between intervention and control groups. The mentioned results are along with the results of SUNNY trial (29). Whereas, Eftekhari and coworkers represented that vitamin D supplementation increased Beta Cells function and conclusively insulin secretion $(p=0.009)$ (32). However, Tabesh and coleagues studied the effect of calcium and vitamin D supplementation and their intervention had decreased fasting serum insulin levels significantly $(\mathrm{p}=0.01)$ (33), and similarly, Yazadn-Rad and his colleagues found that 2 months vitamin D supplementation decreased fasting insulin level significantly ( $p=0.048)$ (34).

The potential mechanisms regarding the effect of vitamin D on insulin level are assumed to be presence of Vitamin D Receptors (VDRs) in pancreas cells, and expression of 1-alpha-hydroxilase in these cells (35). Moreover, there are some elements on human insulin promotors that respond to vitamin $\mathrm{D}$, and can activate transcription of human insulin gene $(36,37)$.

Modification of insulin sensitivity and resistance after intervention was not significant in our study, which is along with Al-Daghri and colleagues' study in 2010, and SUNNY trial $(29,30)$. However, Tabesh and coworker found significant decrease in HOMA-IR and significant increase of QUICKI after weekly intake of 50,000 IU vitamin D and 1000mg calcium per day (33). Yazadan-Rad and colleagues intervention with 4000IU vitamin D for 2 months, represented increased insulin sensitivity (34), and in a cross-sectional study in 2016 there was a negative correlation between $25(\mathrm{OH})$ vitmin D and HOMA-IR after adjusting the analysis for confounders (38).

Modification of insulin resistance and sensitivity after intervention was not significant probably because insulin sensitivity and resistance formulas are dependent on fasting serum glucose and insulin level which increased after intervention.

One of the probable mechanisms of vitamin D associa- 
tion with diabetes and its effect on glucose homeostasis may be probably because of vitamin $\mathrm{D}$ effect of insulin receptor in pancreatic beta cells. In other words, vitamin D may stimulate expression of insulin receptor gene and increase glucose transfer from intestine (39).

On the other side, vitamin D supplementation led to $1 \%$ decrease in HbAlc among intervention group $(\mathrm{p}=0.001)$. These findings are in accordance with Tabesh and colleagues' study (33), Yazadn-Rad and coworkers, and Nasri and coworkers' project (28). Whereas, in Nasri and coworkers' study HbAlc increased after intervention $(p=0.013)$. Al-Sofiani and colleagues demonstrated that HbA1c did not changed considerably after intervention $(p=0.5)(40)$. Sheth and colleagues found $p=0.057$ on the association of serum $(\mathrm{OH})$ vit $\mathrm{D}$ and HbAlc (41). SUNNY trial also did not find any improvement in HbA1c after intervention (29). The explanation for this controversy may be the result of unadjusted potential confounders, and reverse causality in observational studies comparing trials. We did not find a particular mechanism in this regard.

Vitamin D supplementation did not impact LDL cholesterol, TG, and total cholesterol. However, HDL cholesterol increased after intervention which is in accordance with Tabesh and colleagues's study (33), Gannage and coworkers' study in 2009 among 381 non-obese University students (42), and Yazadan-Rad and colleagues' project (34). Tabesh and coworkers attained significant results on decreased LDL cholesterol after intervention (33), and in a cross-sectional study by Liu and coworkers, serum $(\mathrm{OH})$ vit $\mathrm{D}$ was in non-significant positive association with HDL cholesterol and non-significant inverse association with triacylglycerol (43). The mechanism for increased levels of HDL cholesterol would have been related to antiinflammatory and anti-oxidative effect of vitamin $\mathrm{D}$ by increasing Apo lipoprotein A1 after 8 weeks intervention.

AST, ALT, BUN, and Creatinine remained unchanged after intervention probably because the range of mentioned variables was not out of normal levels among the subjects who participated this study.

Furthermore, vitamin D supplementation significantly increased SOD, whereas, modification of Glutathione Peroxidase (GPx) was not significant. Despite, actual mechanism of vitamin D on oxidative stress biomarkers is not clear yet, improvement of cellular Glutathione levels, attenuation of active oxygen species, and pro-inflammatory markers by vitamin $\mathrm{D}$ could be a probable explanation for positive effects of vitamin D on oxidative stress.

Comparing change in ESR and hsCRP inflammatory indices before and after intervention represented significant and nonsignificant differences respectively. These findings are along with Akbarzadeh and coworkers' study (44), and Haidari and colleagues' study (45). But Razzaghi and coworkers' research in 2017 represent different results (46). We may guess the controversy in this area is due to different study designs, fat mass, and variety of inflammation levels, different dose of vitamin D, and intervention period. Inflammatory markers may need time to be improved after vitamin D deficiency.

Systolic and diastolic blood pressure did not change significantly after intervention which is in accordance with Tabesh and coworkers' study (33), SUNNY trial (29), and Nayak and colleagues' study in 2016 (47). Lee and colleagues conducted a study in 2016, and found different results comparing our study (48). In our study, mean systolic and diastolic blood pressure were normal in both intervention and control groups at the baseline, which can make the results of blood pressure expectable.

The main strength of this study was screening subjects of study not only according to serum vitamin D status, but also for other variables such as HbAlc, ESR, AST and ALT, BUN and Creatinine, and cholesterol and TG levels.

The weaknesses and limitations of our study was that we did not use more robust methods for evaluation of insulin resistance and BMI. Furthermore, we did not measure Parathyroid Hormone (PTH), Apolipoprotein A1, and more sensitive inflammatory markers.

\section{Conclusion}

Vitamin D supplementation for 8 weeks with 50000 IU vitamin D may increase levels of $25(\mathrm{OH})$ vitmin $\mathrm{D}, \mathrm{HDL}$ cholesterol, SOD, and decrease levels of glycosylated hemoglobin, and ESR. However, this intervention did not have significant effect on fasting serum glucose and insulin, liver and kidney biomarkers, blood pressure, insulin sensitivity and resistance.

\section{Acknowledgement}

The researchers of this study are thankful to the research chancellor of Iran University of Medical Sciences, Dr Abrishami Laboratory staffs in Bandar-E-Anzali, and all of the individuals who helped us in this project.

\section{Conflict of Interests}

The authors declare that they have no competing interests.

\section{References}

1. Association AD. Diagnosis and classification of diabetes mellitus Diabetes care. 2004;27(suppl 1):s5-s10.

2. Rolim MC, Santos BM, Conceição G, Rocha PN. Relationship between vitamin $\mathrm{D}$ status, glycemic control and cardiovascular risk factors in Brazilians with type 2 diabetes mellitus. Diabetol Metab Syndr. 2016;8(1):77.

3. Himmetoglu S, Teksoz S, Zengin K, Yesim T, Taskın M, Dincer Y. Serum levels of fetuin a and 8-hydroxydeoxyguanosine in morbidly obese subjects. Exp Clin Endocrinol Diabetes. 2013;121(08):505-8.

4. Organization WH. Definition, diagnosis and classification of diabetes mellitus and its complications: report of a WHO consultation. Part 1 , Diagnosis and classification of diabetes mellitus. 1999.

5. Ejtahed H, Mohtadi-Nia J, Homayouni-Rad A, Niafar M, AsghariJafarabadi M, Mofid V, et al. Effect of probiotic yogurt containing Lactobacillus acidophilus and Bifidobacterium lactis on lipid profile in individuals with type 2 diabetes mellitus. J Dairy Sci. 2011;94(7):3288-94.

6. Ray A, Huisman M, Tamsma J, van Asten J, Bingen B, Broeders E, et al. The role of inflammation on atherosclerosis, intermediate and clinical cardiovascular endpoints in type 2 diabetes mellitus. Eur J Intern Med. 2009;20(3):253-60

7. Kimiagar M, Pourshams A, Majd SK, Goglani G, Jaafari E, Semnani $\mathrm{S}$, et al. Vitamin deficiency in Golestan Province, northern Iran: a high-risk area for esophageal cancer. Arch Iran Med. 2010;13(5):391.

8. Heshmat R, Mohammad K, Majdzadeh S, Forouzanfar M, Bahrami A, Ranjbar Omrani G. Vitamin D deficiency in Iran: A multi-center study among different urban areas. Iran $\mathrm{J}$ Public Health. 2008;37(suppl). 
9. Baz-Hecht M, Goldfine AB. The impact of vitamin D deficiency on diabetes and cardiovascular risk. Curr Opin Endocrinol Diabetes Obes. 2010;17(2):113-9.

10. Nimitphong $\mathrm{H}$, Chanprasertyothin S, Jongjaroenprasert W, Ongphiphadhanakul B. The association between vitamin D status and circulating adiponectin independent of adiposity in subjects with abnormal glucose tolerance. Endocrine. 2009;36(2):205-10.

11. Akbari M1, M. M. The Effects of Vitamin D Supplementation on Glucose Metabolism and Lipid Profiles in Patients with Gestational Diabetes: A Systematic Review and Meta-Analysis of Randomized Controlled Trials. Hormon Met Res. 2017; 647-653.

12. Roth CL, Elfers C, Kratz M, Hoofnagle AN. Vitamin D deficiency in obese children and its relationship to insulin resistance and adipokines. J Obes. 2011;2011.

13. Forouhi NG, Luan Ja, Cooper A, Boucher BJ, Wareham NJ. Baseline serum 25-hydroxy vitamin D is predictive of future glycemic status and insulin resistance. Diabetes. 2008;57(10):2619-25.

14. Chiu KC, Chu A, Go VLW, Saad MF. Hypovitaminosis D is associated with insulin resistance and $\beta$ cell dysfunction. Am J Clin Nutr. 2004;79(5):820-5.

15. Alvarez JA, Ashraf A. Role of vitamin D in insulin secretion and insulin sensitivity for glucose homeostasis. Int $\mathrm{J}$ Endocrinol. 2010;2010.

16. Mathieu C, Gysemans C, Giulietti A, Bouillon R. Vitamin D and diabetes. Diabetologia. 2005;48(7):1247-57.

17. Halliwell B. Lipid peroxidation: a radical chain reaction. Free radicals in biology and medicine. 1989.

18. Iyer A, Panchal S, Poudyal H, Brown L. Potential health benefits of Indian spices in the symptoms of the metabolic syndrome: a review. Indian J Biochem Biophys. 2009; 46(6):467-81.

19. Craig CL, Marshall AL, Sjorstrom M, Bauman AE, Booth ML, Ainsworth BE, et al. International physical activity questionnaire: 12country reliability and validity. Med Sci Sports Exerc. 2003;35(8):1381-95.

20. Nikooyeh B, Neyestani TR, Farvid M, Alavi-Majd H, Houshiarrad A, Kalayi A, et al. Daily consumption of vitamin D-or vitamin D+ calcium-fortified yogurt drink improved glycemic control in patients with type 2 diabetes: a randomized clinical trial. Am J Clin Nutr. 2011;93(4):764-71.

21. Matthews D, Hosker J, Rudenski A, Naylor B, Treacher D, Turner R. Homeostasis model assessment: insulin resistance and $\beta$-cell function from fasting plasma glucose and insulin concentrations in man. Diabetologia. 1985;28(7):412-9.

22. Katz A, Nambi SS, Mather K, Baron AD, Follmann DA, Sullivan G, et al. Quantitative insulin sensitivity check index: a simple, accurate method for assessing insulin sensitivity in humans. J Clin Endocrinol Metab. 2000;85(7):2402-10.

23. Baziar N, Jafarian K, Shadman Z, Qorbani M, Nikoo MK, Mishani MA. Effect of therapeutic dose of vitamin D on serum adiponectin and glycemia in vitamin D-insufficient or deficient type 2 diabetic patients. Iran Red Crescent Med J. 2014;16(9)

24. Holick MF, Binkley NC, Bischoff-Ferrari HA, Gordon CM, Hanley DA, Heaney RP, et al. Evaluation, treatment, and prevention of vitamin D deficiency: an Endocrine Society clinical practice guideline. J Clin Endocrinol Metab. 2011;96(7):1911-30.

25. Association WM. World Medical Association Declaration of Helsinki. Ethical principles for medical research involving human subjects. Bulletin of the World Health Organization. 2001;79(4):373.

26. Borissova A, Tankova T, Kirilov G, Dakovska L, Kovacheva R. The effect of vitamin D3 on insulin secretion and peripheral insulin sensitivity in type 2 diabetic patients. Int J Clin Pract. 2003;57(4):25861.

27. Heshmat R, Tabatabaei-Malazy O, Abbaszadeh-Ahranjani S, Shahbazi S, Khooshehchin G, Bandarian F, et al. Effect of vitamin D on insulin resistance and anthropometric parameters in Type 2 diabetes; a randomized double-blind clinical trial. J Pharm Sci. 2012;20(1): 10 .

28. Nasri H, Behradmanesh S, Maghsoudi AR, Ahmadi A, Nasri P, Rafieian-Kopaei M. Efficacy of supplementary vitamin D on improvement of glycemic parameters in patients with type 2 diabetes mellitus; a randomized double blind clinical trial. J Renal Inj Prev. 2014;3(1):31.

29. Krul-Poel YH, Westra S, ten Boekel E, ter Wee MM, van Schoor $\mathrm{NM}$, van Wijland $\mathrm{H}$, et al. Effect of vitamin D supplementation on glycemic control in patients with type 2 diabetes (SUNNY trial): a randomized placebo-controlled trial. Diabetes Care. 2015;38(8):1420

30. Al-Daghri N, Al-Attas O, Alokail M, Alkharfy K, Draz H, Clerici M. Serum 25-hydroxy-vitamin D is associated with adiponectin and insulin resistance in diabetic Saudi adults. J Endocrinol Invest. 2013; $6(1): 1-6$

31. Nielsen NO, Bjerregaard P, Rønn PF, Friis H, Andersen S, Melbye $\mathrm{M}$, et al. Associations between Vitamin D status and type 2 diabetes measures among Inuit in Greenland may be affected by other factors. PloS one. 2016;11(4):e0152763.

32. Eftekhari M, Akbarzadeh M, Dabbaghmanesh M, Hasanzadeh J. Effects of treatment with oral calcitriol on plasma glucose and insulin levels in non-insulin dependent diabetes mellitus patients. J Food Technol Nutr. 2011;6(3):1-10.

33. Tabesh M, Azadbakht L, Faghihimani E, Tabesh M, Esmaillzadeh A. Effects of calcium-vitamin D co-supplementation on metabolic profiles in vitamin $\mathrm{D}$ insufficient people with type 2 diabetes: a randomised controlled clinical trial. Diabetologia. 2014;57(10):203847.

34. Rad EY, Djalali M, Koohdani F, Saboor-Yaraghi AA, Eshraghian MR, Javanbakht MH, et al. The effects of vitamin D supplementation on glucose control and insulin resistance in patients with diabetes type 2: a randomized clinical trial study. Iran J Public Health 2014;43(12):1651

35. Johnson JA, Grande JP, Roche PC, Kumar R. Immunohistochemical localization of the $1,25(\mathrm{OH}) 2 \mathrm{D} 3$ receptor and calbindin D28k in human and rat pancreas. Am J Physiol Endocrinol Metab. 1994;267(3):E356-E60

36. Maestro B, Molero S, Bajo S, Davila N, Calle C. Transcriptional activation of the human insulin receptor gene by 1,25 dihydroxyvitamin D3. Cell Biochem Funct. 2002;20(3):227-32.

37. Maestro B, Dávila N, Carranza MC, Calle C. Identification of a Vitamin $\mathrm{D}$ response element in the human insulin receptor gene promoter. J Steroid Biochem Mol Biol. 2003;84(2):223-30.

38. Zhang J, Ye J, Guo G, Lan Z, Li X, Pan Z, et al. Vitamin D status is negatively correlated with insulin resistance in Chinese type 2 diabetes. Int J Endocrinol. 2016;2016

39. Maestro B, Campión J, Dávila N, Calle C. Stimulation by 1, 25dihydroxyvitamin D3 of insulin receptor expression and insulin responsiveness for glucose transport in U-937 human promonocytic cells. Endocrine journal. 2000;47(4):383-91.

40. Al-Sofiani ME, Jammah A, Racz M, Khawaja RA, Hasanato R, ElFawal HA, et al. Effect of vitamin D supplementation on glucose control and inflammatory response in type II diabetes: a double blind, randomized clinical trial. Int J Endocrinol Metab. 2015;13(1).

41. Sheth JJ, Shah A, Sheth FJ, Trivedi S, Lele M, Shah N, et al. Does vitamin D play a significant role in type 2 diabetes? BMC Endocr Disord. 2015; 15(1):5.

42. Gannagé-Yared MH, Chedid R, Khalife S, Azzi E, Zoghbi F, Halaby G. Vitamin D in relation to metabolic risk factors, insulin sensitivity and adiponectin in a young Middle-Eastern population. Eur J Endocrinol. 2009;160(6):965-71

43. Liu E, Meigs JB, Pittas AG, McKeown NM, Economos CD, Booth $\mathrm{SL}$, et al. Plasma 25-hydroxyvitamin D is associated with markers of the insulin resistant phenotype in nondiabetic adults. J Nutr. 2009;139(2):329-34

44. Akbarzadeh M, Eftekhari MH, Dabbaghmanesh MH, Hasanzadeh J, Bakhshayeshkaram M. Serum IL-18 and hsCRP correlate with insulin resistance without effect of calcitriol treatment on type 2 diabetes. Iran J Immunol. 2013;10(3): 167.

45. Haidari F, Zakerkish M, Karandish M, Saki A, Pooraziz S. Association between serum Vitamin D level and glycemic and inflammatory markers in non-obese patients with type 2 diabetes. Iran J Med Sci. 2016;41(5):367

46. Razzaghi R, Pourbagheri H, Momen-Heravi M, Bahmani F, Shadi J, Soleimani $Z$, et al. The effects of vitamin D supplementation on wound healing and metabolic status in patients with diabetic foot ulcer: a randomized, double-blind, placebo-controlled trial. J Diabetes Complications. 2017;31(4):766-72.

47. Nayak SB, Ramnanansingh TG. Evaluation of vitamin D relationship with type 2 diabetes and systolic blood pressure. BMJ Open Diabetes Res Care. 2016;4(1):e000285.

48. Lee KJ, Lee YJ. Effects of vitamin D on blood pressure in patients with type 2 diabetes mellitus. Int $J$ Clin Pharmacol Ther. 2016;54(4):233. 